\title{
Morfologia dos nectários e concentração dos néctares de algumas plantas apícolas *
}

\author{
CLOVIS FERRAZ DE OLIVEIRA SANTOS
}

Assistente Contratado da 3a. Cadeira

Escola Superior de Agricultura "Luiz de Queiroz"

Universidade de S. Paulo - Piracicaba

\section{INDICE}

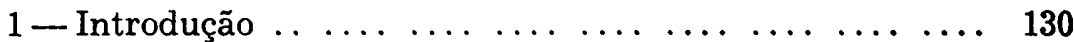

2 - Material e método .......................... 131

3-Observações nas espécies estudadas . . . .......... 131

4 - Resumo e Conclusões . . . . . . . . . . . . . . . . . . 144

$\begin{array}{llllllllllll}5-\text { Bibliografia } \ldots & \ldots & \ldots & \ldots & \ldots & \ldots & \ldots & \ldots & \ldots & \ldots & 145\end{array}$

$\begin{array}{lllllllllll}6 \text {-Legendas } & \ldots & \ldots & \ldots & \ldots & \ldots & \ldots & \ldots & \ldots & \ldots & \ldots\end{array}$

O presente trabalho foi realizado nos laboratórios da 3a. Cadeira (Botanica Geral e Descritiva) da E. S. A. "Luiz de Queiros", com equipamento doado a Cadeira pela Fundaça Rockefeller e Conselho Nacional de Pesquisas. 


\section{INTRODUÇĀO}

Apesar da crescente utilidade da flora apícola como fonte de pólen e néctar, poucos estudos foram feitos no Brasil com relação a êsse fascinante campo da Botânica.

O conhecimento da flora apícola é de grande importância, pois, como pondera HOWES (1945), sem fonte adequada e abundante suprimento de néctar e pólen os apicultores não poderão obter mel.

Como é óbvio, tôda exploração apícola deve visar o maior aproveitamento possivel das riquezas que a vegetação natural oferece expontânea e gratuitamente, razão por que um conhecimento cada vez maior das plantas úteis às abelhas se torna indispensável para se alcançar aquêle objetivo.

De acôrdo com ORDETX (1952), a flora apicola pode ser encarada sob dois aspetos diferentes: plantas produtoras de pólen (flora polinífera) e plantas fornecedoras de néctar (flora nectarífera), muito embora haja plantas que forneçam simultâneamente pólen e néctar (flora nectar-polinífera).

Interessados que estamos no estudo dessa flora, na região de Piarcicaba, reunimos neste trabalho os resultados de nossas observações iniciais.

Julgamos que as nossas observações possam fornecer aos interessados nesse gênero de estudo dados $e$ informações quanto à forma, tamanho, localização dos nectários nas diferentes peças florais, e sua estrutura anatômica, bem como se as plantas nectaríferas que estudámos têm florescimento abundante, elevada produção de néctar, e qual a sua concentração em açúcares. Também verificámos, sempre que nos foi possível, a visita das abelhas (Apis mellifera L., Trigona ruficrus Lat., Trigona hyalinata Lt.,) procurando saber se a estrutura e a conformação das flôres lhes favoreciam o acesso para a coleta do néctar.

O néctar das plantas é o produto das glândulas nectaríferas, ou órgãos morfològicamente definidos, especializados na produção de néctar - os nectários.

A secreção do néctar é uma das mais extraordinarias funções da vida das plantas. Sua produção depende não apenas da ação dos diversos fatores que atuam simultâneamente sôbre a planta como também, da própria planta.

O presente trabalho é uma condensação da 1a. Parte da tése para Doutoramento, apresentada à E. S. A. "Luiz de Queiroz" e aprovada em concurso em 1954. 


\section{MATERIAL E METODO}

O material para o estudo dos nectários foi quase todo colhido nos terrenos da E. S. A. "Luiz de Queiroz" e imediações, com exceção do de Coffea arabica, L. var. semperflorens e Cinchona Succirubra, que veio do Instituto Agronômico de Campinas.

Ao procedermos a coleta do material, tivemos o cuidado de verificar se as plantas esiavam em período de florescimento, se segregavam néctar ou se eram visitadas ou não por abelhas (Apis e Trigona) e como elas taziam o trabalho de colheita do néctar e isto durante o periodo compreendido entre dezembro de 1953 a outubro de 1954.

As plantas escudadas, quase tódas, foram identificadas por nós, algumas pelo Dr. Dalvo Mattos Dedecca (Chefe da Seç̧ão ce Botânica do Instituto Agronomico de Campinas), outras pelo Prof. Philippe Westim Cabral de Vasconcelos e Dr. Warwick Kerr que também se ocupa de tão interessante assunto.

Para coleta do néctar utilizamos uma pequena seringa de injeção e de uma agulha sem ponta. A deiermınação da concentração foi feita com dois refratômetros de campo, da marca Huet, sendo um de graduaçáo de $0 \%$ a $50 \%$ e o outro de $50 \%$ a $80 \%$.

Adotámos o método direto de coleta do néctar, isto é, servimo-nos das flòres recém abertas, destacadas da planta. A exuraçãu do néctar foi feita no próprio local ou no laboratório com o auxílio de um microscópio esieroscópico.

Uma vez retirado o néctar de cada flor era o mesmo levado au refratômetro para verificarmos e anotarmos a sua concentração e a seringa, a seguir, lavada com álcool absoluto e só utilizada novamente, quando bem sêca.

Registrámos sempre a hora, dia, mês em que fazíamos o leitura da concentração, conforme se vê na descrição de cada espécie.

\section{OBSERVAÇÕES NAS ESPÉCIES ESTUDADAS}

\section{1. - Família Bignoniaceae}

Bactocydia unguis, Matr.

Nome vulgar : Cipó-de-gato

Florescimento: Floresce em grande quantidade nos meses de junho, julho e agôsto pelos campos, sôbre as cêrcas da árvores sêcas. 
O néctar e as abelhas: As flôres são visitadas por abelhas (Apis e Trigona).

$\mathrm{O}$ néctar, muito abundante, enche o tubo da corola (corola campanulada infundibuliforme) o qual possue $1 \mathrm{~cm}$ de comprimento na sua porção mais estreita. As abelhas (Apis), uma vez no interior da flor, atingem a regiāo estreita, revestida de pêlos comuns e, a seguir, introduzem a língua no tubo da corola para sugar o néctar. As irapuás também retiram o néctar, porém, furam a base do tubo da corola.

Concentração do néctar em açúcares : $36,40,39,38$, e $39 \%$, (cada um dos valures corresponde ao néctar de uma flor), em 22-7-54, às 14 horas. C. M. $38,6 \%$.

$40,42,42,43,43,42 \%$, (cada um dos valores corresponde ao néctar de cada um dos neciários extraflurais), em 22-7-54, às 14 horas. C. M. $42 \%$.

Nectário : Apresenta-se como um disco glanduluso, de consistência carnosa, pouco mais largo que alto, situado no receptáculo e hipóginc. Compurta-se cumo um pedestal do ovário (súpero). Esta espécie possui, ainda, numerosos nectários extraflorais, localizados irregularmente nas brácteas e na superfície externa das sépalas, muito pequenas e com forma de um tronco de cône. Sôbre êle aparece uma gota de néctar, quando em secreçāo.

Pyrostegia ignea, Presl.

Nome vulgar: Flor-de-São-João

Florescimento: Floresce em profusão nos meses de junho, julho, agòsto e principalmente de setembro até outubro.

O Néctar $e$ as abelhas: Suas flüres, por terem uma corola de tubo longo ( $4 \mathrm{~cm}$ de comprimento) e inteiro, não favorecem 0 acesso às abelhas (Apis). O néctar acumula-se no tubo da corola, em grande quantidade. Entretanto, as irapuás (Trigona) furam a base do tubo da corola e sugam o néctar. As abelhas (Apis) por seu turno, aproveitam-se daquele orifício para coletar o néctar. A secreção do néctar é de pequena duração, pois, logo após a queda da corola, ela diminui consideràvelmente até cessar por completo.

Concentração do néctar em açúcares : 16, 18, 19, 21, 21, 21, $23 \%$, (cada um dos valores corresponde ao néctar de uma flor), em 21-6-1954, às 14 horas. C. M. 19,8\%.

Nectário: Possui a mesma situação do nectário da espécie anterior, e quanto à forma é, também, um disco, porém mais cilíndrico e mais desenvolvido. 


\subsection{Família Compositae}

Montanoa bipinnatifida, C. Koch

Nome vulgar: Margarida-de-árvore

Florescimento: Floresce de preferência nos meses de maio, junho, julho, agôsto até setembro.

$O$ Néctar $e$ as abelhas: As flôres são frequentemente visitadas por abelhas. (Apis e Trigona). O néctar acumula-se no tubo da corola e é alí que as abelhas introduzem a língua (6mm de comprimento), conseguindo, com facilidade, a retirada do néctar. Outra circunstância que favorece a coleta du néctar pelas abelhas é o fato de a antese ser centrípeta e as lacínias da corola curtas.

Concentração do néctar em açúcares : $38,41,43,42,42,44 \%$, (cada um dos valores corresponde ao néctar de uma flor), em $15-6-54$, às 10 horas. C. M. $41,4 \%$.

Nectário: E' um disco carnoso, bem destacado, quasi esférico, visível a ôlho nú, situado na base do estilête, na região onde êle se prende ao ovário (Fig. 1, C). O tubo da corola não só protege o nectário como serve de depósito do néctar, que nele se acumula. Os nectários sòmente ocorrem nas flôres hermafroditas.

Vernonia polyanthes, Less.

Nome vulgar: Assa-peixe

Florescimento: Floresce nos meses de junho, julho, agôsto. E' bastante comum nos pastos e terrenos.

$O$ Néctar $e$ as abelhas: As flôres são muito visitadas por abelhas, (Apis e Trigona). O néciar acumula-se no tubo da :0rola, cujo comprimento é de $5 \mathrm{~mm}$. Em virtude de a florescência ser centrípeta, as flôres não se abrem simultâneamente, de modo que as abelhas encontram nos capítulos de Vernonia, durante certo tempo, excelente fonte de néctar.

E' considerada como uma das melhores plantas apícolas, nativas entre nós, pois são abundantíssimas em nossa regi-i

Concentração do néctar em açúcares : $34,35,36,36,37$ :'r (cada um dos valores corresponde ao néctar de uma flor), em $15-7-54$, às 11 horas. C. M. 35,6\%.

Nectário: Em linhas gerais, o nectário de Vernonia assemelha-se ao da espécie anterior, sendo, porém de tamanho menor. 


\subsection{Família Convolvulaceae}

Ipomoea purpurea, Lam.

Nome vulgar: Bons-dias

Florescimento: Floresce entre nós nos meses de maio, junho, julho, agôsto, pelos terrenos abandonados, subindo pelas cêrcas, troncos de árvores, etc.

O Néctar e as abelhas: As flôres são visitadas por abelhas (Apis e Trigona). O néctar acumula-se no tubo da corola, na sua parte basal e estreita. As abelhas Apis penetram no interior da corola que é bem aberta (pela manhã), até a região mais estreita e, dali, introduzem a sua tromba e sugam o néctar. As Trigona, ao contrário, furam a base do tubo da corola para a retirada do néctar.

Concentração do néctar em açúcares : 48, 46, 50, 44, 45, 44, $46 \%$, (cada um dos valores corresponde ao néctar de uma flor), em 27-7-54, às 11 horas. C. M. 46,1\%.

Nectário: Tem a forma de uma taça e situa-se no tôpo do receptáculo, em cujo interior se assenta o ovário. Entre êste e os bordos do nectário existe um pequeno espaço que fica cheio de néctar.

\subsection{Família Cruciferae}

Brassica juncea, Coss.

Nome vulgar: Mostarda

Florescimento: Floresce em junho, julho, agôsto até setembro.

O Néctar e as abelhas: As flôres são muito visitadas por abelhas (Apis e Trigona). O néctar, produzido em pequena quantidade, acumula-se nas 4 sépalas, levemente côncavas, com os bordos recurvados para a página superior, servindo, assim, de reservatório ao néctar.

Concentração do néctar em açúcares : $36,35,34,34,34,28$, $28,30,34,31,36 \%$, (cada um dos valores corresponde ao néctar de uma flor), em 27-7-54, ảs 11 horas. C. M. $32 \%$.

Nectário : São 4 os nectários - dois bem clavados e os outros dois globosos, de superfície facetada. Situam-se no receptáculo, em frente às 4 sépalas e alternam com os 4 estames maiores. Os dois estames menores e mais externos são opostos e se acham intercalados entre um nectário e uma sépala. ( Fig.2,C)

Eruca sativa, Mill.

Nome vulgar: Rúcula

Florescimento: Nas hortas onde é cultivada, floresce durante várias épocas do ano. 
O Néctar e as abelhas: As flôres são visitadas por abelhas (Apis e Trigona). O néctar deposita-se nas 4 sépalas, que são maiores do que as da mostarda, porém, com a mesma conformação, servindo como reservatório do néctar.

Concentração do néctar em açúcares : $31,30,29,30,31,30$, $31 \%$, (cada um dos vàlores corresponde ao néctar de uma flor), em 27-7-54 às 10 horas. C. M. $30,1 \%$.

Nectário: O néctar é produzido por 4 nectários situados na flor e têm a mesma disposição e aspecto dos nectários da mostarda. Ver figura $9-C$.

\subsection{Familia Euphorbiaceae}

Euphorbia pulcherrima, Willd.

Nome vulgar: Flor-de-papagaio, fôlha-de-sangue

Florescimento: Floresce nos meses de junho, julho, agôsto, setembro até outubro.

O néctar e as abelhas: Suas flôres são visitadas pelas abelhas (Apis e Trigona) que delas extraem fàcilmente o néctar acumulado, em quantidade apreciável, no interior da concha nectarífera. A produção de néctar é, às vêzes, tão abundante que chega a transbordar.

Concentração do néctar em açúcares : 20, 20, 19, 26, 23, 25, $26 \%$, (cada um dos valores corresponde ao néctar de uma flor), em 5-10-54, às 14 horas. C. M. $22,7 \%$.

Nectário : O nectário localiza-se no invólucro globoso justapôsto às flôres masculinas. Ele tem o aspecto de uma "pia concheada", colorida de amarelo-esverdeado (Fig. 3, C).

\subsection{Familia Flacourtiaceae}

Aberia caffra, Hock. f. \& Harv.

Nome vulgar: Abéria-cafra

Florescimento: Floresceu, em 1953, nos meses de dezembro a fevereiro e também em agôsto e setembro, principalmente as masculinas. (Pois as flôres são unisexuadas, e em pés separados).

O néctar e as abelhas: As flôres masculinas são visitadíssimas pelas abelhas (Apis e Trigona), àvidas de seu abundante néctar, que se acumula por tôda a extensão da superfície do receptáculo glanduloso. São de fácil acesso às abelhas que não encontram obstáculo no seu trabalho de coleta do néctar.

Concentração do néctar em açúcares : $11,10,11,13,10,15$, $15,16,14,13,12 \%$, (cada um dos valores corresponde ao néctar de uma flor), em 8-10-54, às 9 horas. C. M. $12.6 \%$. 
Nectário: O néctar é produzido copiosamente pelo tecido glandular que reveste os numerosos segmentos prismáticos, de superfície ondulada, de que se compooe o receptáculo; nas depressões entre segmentos estão inseridos os estames:

\subsection{Família Labiatae}

Leonurus sibirucus, $\mathbf{L}$.

\section{Nome vulgar: Rubim, Herva-de-Macaé}

Florescimento: Floresce em várias épocas do ano pelos terrenos baldios e cultivados, sendo considerada como erva invasora. Prcduz mais flôres nos meses de maio, junho e julho.

$O$ néctar $e$ as abelhas: As flôres são visitadas por abelhas (Apis e Trigona) e insetos. Em virtude de o tubo da corola ser curto $(0,5 \mathrm{~cm}$ de comprimento), as abelhas conseguem com facilidade atingir cum a língua o néctar, sugando-o.

Concentração do néctar em açúcares : $22,21,20,22,22,21$, $20 \%$, (cada um dos valores correspondente ao néctar de uma flor), em 17-12-53, às 9 horas. C. M. 21,1\%.

Nectário: O nectário localiza-se no receptáculo e tem a forma de um disco carnoso bem visível, hipógino, ligeiramente escavado na parte superior onde se assenta o ovário súpero. (Fig. 4, C).

Salvia splendens: Sellow

Nome vulgar: Cardeal-do-Brasil, Cardeal-do-México, Sangue-de-Adão

Florescimento: Floresce quase que durante o ano todo, principalmente nos meses de novembro, dezembro, janeiro, fevereiro, março e abril.

O néctar e as abelhas: Suas flóres são visitadas, em geral, por abelhas (Apis e Trigona), além de outros insétos. Como o tubo da corola é muito mais comprido do que a língua da abelhas $(6,0 \mathrm{~mm}$ de comprimento), estas não conseguem recolher o néctar cum facilidade, que nele se acumula. Entretanto, as irapuás (Trigona) conseguem recolhê-lo, penetrando no cálice, de onde furam o tubo da corola, bem na base. Posieriormente as abelhas, aproveitando-se do mesmo orifício, fazem também a sua colheita, uma vez que a secreção do néctar dura alguns dias. A posição da flor na raque e a conformação levemente recurvada do tubo da corola asseguram a remução do néctar para longe das glândulas secretoras, garantindo, assim, uma ininterrupta secreção. $O$ lábio inferior, côncavo, impede que o néctar possa derramar-se para fora, perdendo-se. 
Concentração do néctar em açúcares: $21,23,21,20,24,21$, $20,24,22,23,22,20,21 \%$, (cada um dos valores corresponde ao néctar de uma flor), em 24-4-54, às 9 horas. C. M. 21,07\%.

Nectário: O nectário é um órgão carnoso, bastante volumoso, inserido no receptáculo, galeiforme, isto é, semelhante a um elmo. Em sua cavidade assenta-se o ovário que, por sua vez, é parcialmente protegido pela expansão lateral, conforme se vê na Fig. 5 , C.

\subsection{Família Lauraceae}

Persea americana, Mill.

Nome vulgar: Abacateiro

Flcrescimento: Floresce em agôsto e setembro.

O néctar e as abelhas: As flôres são visitadíssimas por abelhas, ávidas de seu àbundante pólen e néctar. O néctar acumula-se quer na superfície das próprias glândulas, quer na base das peças do perianto.

Concentração do néctar em açúcares : 49, 48, 46, 48, 48, 48, $47,44,45,44,48,48 \%$, (cada um dus valores corresponde ao néctar de um flor)., em 13-9-54, às 10 horas. C. M. 46,9\%.

Nectário: As glândulas produtcras de néctar estão situadas na base dos três estames da série mais interna, em número de dois para cada estame. São de origem estaminal (Fig. 6, B.), de forma oval-achatada e de côr alaranjada.

\subsection{Familia Leguminosae}

Caesalpinia sepiaria, Roxb.

Nome vulgar: Espinho-de-cêrca ou marica

Florescimento: Floresce nos meses de junho, julho até outubro.

$O$ néctar e as abelhas: As flôres são de fácil acesso às abelhas (Apis e Trigona) que as visitam com frequência. $O$ néctar segregado acumula-se na superfície do receptáculo, entre a corôa dos estames e o ovário.

Concentração do néctar em açúcares : $61,75,69,68,69,61$, $63,66,67,56,69,65 \%$, (cada um dos valores corresponde ao néctar de uma flor), em 10-8-54, às 14 horas. C. M. 67,8\%.

Nectário : O tecido secretor do néctar é o próprio tecido que reveste a superfície do resceptáculo floral, por tôda a extensão superior, compreendida entre os estames e o ovário súpero.

Crotalaria paulinia, Schranck

Nome vulgar: Manduvira-grande

Florescimento: Floresce nos meses de março a julho. 
O néctar e as abelhas: As flôres são visitadas por abelhas (Apis e Trigona). O néctar, à medida que é produzido, deposita-se sôbre o próprio tecido secretor, no espaço entre o ovário e os estames soldados e, às vêzes, sôbre a base da carena. Uma vez que são nove esiames soldados e um livre, o néctar escoa-se pelos estames soldados e o livre.

Concentração do néctar em açúcares : $50,63,62,72,73,62$, $68 \%$, (cada um dos valores corresponde au néctar de uma flor), em 2-8-54, às 13 horas. C. M. 65,2\%.

Nectário: E' constituido do tecido glandular que reveste a superfície interna do recptáculo e, também, pelo tecido basal que recobre o ovário (súpero).

Dolichos lablab, Lineu

Nome vulgar: Cumandatiá

Florescimento: Floresce em várias épocas do ano, mas principalmente de maio a agôsto.

O néctar e as abelhas: As flôres são visitadas por abelhas (Apis e Trigona). O néctar armazena-se entre os estames e o ovário, na superfície do receptáculo e, também, na base de uma das pétalas recurvadas que retêm o néctar. O néctar, em virtude da posição das flôres e de suas peças, escorre do tecido secretor (nectário), através dos espaços deixados pelos estames soldados e o estame livre. A Apis consegue retirar o néctar, introduzindo a sua tromba pelo espaço entre a carena e as pétalas ( 2 azas).

Concentração do néctar em açúcares : $60,60,61,60,60,60$, $59,60,61 \%$, (cada um dos valores corresponde ao néctar de uma flor), em 27-i-54, às 15 horas. C. M. $60,1 \%$.

Nectário : E' um anel alto, constituido pela concrescência de numerosas lâminas carnosas, que circundam a base do ovário. O bordo do anel é sinuoso e irregular, e assemelha-se, pelo aspeto, ao nectário de Grevillea Thelemanniana.

\subsection{Família Loganiaceae}

Buddleia brasiliensis, Jacq. F.

Nome vulgar: Barbasco, Verbasco-Brasil, Calção-de-velha

Florescimento: Florece abundantemente nos terrenos abandonados, nos meses de maio, junho, julho e agôsto.

O néctar e as abelhas: As flôres de Buddleia brasiliensis, Jacq. F. são muito aromáticas e bastante visitadas pelas abelhas (Apis) que delas retiram pólen e o abundante néctar que segregam, o qual, embora se acumule no tubo da corola $(6 \mathrm{~mm}$ 
de comprimento), está fàcilmente ao alcance das trombas das abelhas.

Concentração do néctar em açúcares : $66,66,65,66,66,65$, $64,66,66,66 \%$, (cada um dos valores corresponde ao néctar de uma flor), em 18-5-54, às 14 horas. C. M. 65,6\%.

Nectário: E' um tecido secretor que reveste a parte basal do ovário (súpero).

\subsection{Familia Malvaceae}

Hibiscus rosa sinensis, $L$.

Nome vulgar: Mimo-de-Vênus, Hibisco

Florescimento: Ocorre quase que durante o ano todo, mas principalmente nus meses de maio a agôsto.

$O$ néctar e as abelhas: As flôres são pouco visitadas pelas abelhas (Apis e Trigona). As abelhas (Apis) conseguem retirar o néctar que se junta na parte basal do tubo da corola, com $1,2 \mathrm{~cm}$ de comprimento, introduzindo a língua pelos espaços existente na região onde $o$ andróforo se liga às pétalas. As irapuás (Trigona), entretanto, conseguem retirar o néctar do tubo da corola, perfurando a base du cálice e da corola. Dêsse orifício aproveitam-se, posteriomente, as abelhas para coletar o néctar.

Concentração do néctar em açúcares: 20, 21, 21, 20, 19, $20 \%$, (cada um dos valores corresponde ao néctar de uma flor), em 2-8-54, às 15 horas. C. M. 20,00\%.

Nectário : E' compôsto de pêlos glandulares, localizados na face interna e na base das sépalas que formam o cálice tubuloso (campanulado), com o aspecto de uma almofada.

\subsection{Familia Myrtaceae}

Eucalyptus rostrata, Schlecht

Nome vulgar: Eucalipto bro.

Florescimento: Dá-se nos meses de julho, agôsto e setem-

O néctar e as abelhas: As flôres são muitíssimo visitadas pelas abelhas (Apis e Trigona). O néctar deposita-se na depressäo entre o ovário e o receptáculo, em quantidade bastante apreciável. As abelhas introduzem a tromba por entre os estames livres ou por cima deles (entre êles e o ovário) e retiram o néctar. 
Concentração do néctar em açúcares : $64,64,69,61,67,71$, $66,80,79,80 \%$, (cada um dos valores corresponde ao néctar de uma flor), em 10-8-54, às 15 horas. M. C. 70,7\%.

Nectário: O tecido secretor do néctar localiza-se no recptáculo e tem forma de um anel saliente amarelo, que rodeia a porção superior do ovário ínfero, aderente ao recptáculo escavado.

Eucalyptus tereticornis, Smith.

Nome vulgar: Eucalipto

Florescimento: Floresce bastante nos meses de abril a setembro.

$O$ néctar e as abelhas: Flôres numerosas, e quando abertas lhes faltam o cálice e a corola (caducos), podendo-se ver os estames, em grande número, nos bordos do receptáculo, à semelhança de coròa branca, muito vistosa. As flôres são de fácil acesso às abelhas (Apis e Trigona), que procuram com avidez seu precioso néctar; êsce junla-se entre a corôa de estames e o gineceu, sôbre a superiicie do lecıdo glandular (nectário) e no resto do receptáculo. Entretanto, é mais comum o néctar se acumular por tôda a extensão, rodeando a corôa dos estames, em virtude da pusição inclinada e cônica da parte superior du receptáculo.

Concentração do néctar em açúcares : 79, 75, 80,79,75, 76, $' i 4,70,71,78, i 8 \%$, (cada um dos valores corresponde ao néctar de uma flor), em 2-8-54, às 15 horas. C. M. 75,9\%.

Nectário: Compõe-se de um tecido glandular, situado no receptáculo, na superfície entre os estames e o estilête, com a forma de uma corôa de cór parda e bem saliente, que rodeia a parte superior do ovário infero, aderente ao receptáculo.

\subsection{Família Polygonaceae}

Antigonum leptopus, Hook e Arn.

Nome vulgar: Amor-agarrado, Coral

Florescimento: Floresce abandantemente entre nós, em várias épocas do ano, porém mais comumente nos meses de agôsto a maio.

$O$ néctar e as abelhas: As flôres são frequentemente procuradas por abelhas (Apis e Trigòna). O néctar é produzido em abundância, razão pela qual esta especie é considerada planta nectarífera de primeira órdem, devendo ser cultivada nas proximidades dos apiários: O néctar enche o espaço compreendido entre $o$ androceu e o ovário e também entre o androceu e as pétalas. 
Concentração do néctar en açúcares: 46, 46, 46, 44, 46, 47, $50,47,47,44 \%$, (cada um dos valores corresponde ao néctar de uma flor), em 21,6-54, às 11 horas. C. M. $46,3 \%$.

Nectário: Consta de numerosus pêlos glandulares, exparsos pela superfície basal dos estames, nas faces interna e externa, bem como na base das sépalas.

\subsection{Família Proteaceae}

Grevillea Thelemanniana, Hueg. (Grevillea preissi, Meissn)

Nome vulgar: Grevílea

Florescimento: Ocorre de preferência nos meses de julho, agôsto, setembro até outubro.

$O$ néctar $e$ as abelhas: As flôres são muito visitadas por abelhas (Apis e 'Trigona) que encontram facilidade na retirada do abundante néctar retido no tubo do cálice, que é fendido até a base, em oposição ao nectário. As irapuás (Trigona) furam o tubo do cálice, bem em frente ao nectário para retirar o néctar.

Concentração do néctar em açúcares: $30,30,29,30,28,29$, $30,31,30 \%$, (cada um dos valores corresponde ao néctar de uma flor), em 13-8-54, às 13 horas. C. M. $29,6 \%$.

Nectário : E' um órgão glanduloso, de superfície irregular, surgindo como uma emergência semi-circular do receptáculo (Fig. $7, \mathrm{C})$ rodeando o ovário súpero e piloso.

\subsection{Familia Rosaceae}

\section{Prunus persica, L.}

Nome vulgar: Pêssegueiro

Florescimento: Floresce entre nós nos meses de junho, julho e agôsto.

$O$ Néctar $e$ as abelhas: Flôres frequentemente visitadas pelas abelhas (Apis e Trigona) para a coleta do néctar e pólen. A conformação da corola, com pétalas bem abertas e estames livres, facilita a coleta do néctar que se acumula em pequenas gotículas no interior do receptáculo, no espaço existente entre êle e o ovário. Essas gotículas ficam retidas nos pêlos não glandulares que se encontram no receptáculo, internamente e ainda na superfície do ovårio. A abelha Apis introduz a sua língua por entre os estames, atingindo o interior do receptáculo que tem $4 \mathrm{~mm}$ de altura.

Concentração do néctar em açúcares: $24,23,23,24,25,23$, $22,25,25,25,25 \%$, (cada um dos valores corresponde ao néctar de uma flor), em 23-7-54, às 10 horas. C. M. 23,7\%. 
Nectário : O tecido glandular produtor do néctar se encontra na parte basal e interna do receptáculo por tôda a sua extensão. E' colorido, de um amarelo alaranjado, um pouco mais saliente do que o resto da superfície do receptáculo.

\subsection{Família Rubiaceae}

Cinchona succirubra Pav.

Nome vulgar: Quineira

Florescimento: Junho, julho e setembro.

O néctar $e$ as abelhas: As flôres são visitadas com frequência pelas abelhas (Apis e Trigona) que extraem o néctar depositado no tubo da corola.

Concentração do néctar em açúcares : 25,27,24, 28, 28, 27\%, (cada um dos valores corresponde ao néctar de uma flor), em 15-6-54, às 10 horas. C. M. 26,1\%.

Nectário: Possui forma e localização semelhante ao de Coffea arabica, L. var. semperflorens.

Coffea arabica, L. var. semperflorens

Nome vulgar: Cafeeiro

Florescimento: Em quase tôdas as épocas do ano.

$O$ néctar $e$ as abelhas: Suas flôres são muito visitadas pelas abelhas (Apis e Trigona), que colhem o néctar acumulado no tubo da corola.

Concentração do néctar em açúcares : $32,36,40,32,36,36$, $38 \%$, (cada um dos valores corresponde ao néctar de uma flor), em $15-6-54$, às 10 horas. C. M. $35,2 \%$.

Nectário: Situa-se entre os receptáculo floral e a parte superior do ovário. (Fig. 8, D)

\subsection{Família Rutaceae}

Citrus aurantifolia, (Chrostm.) Swing.

Nome vulgar: Lima-da-Pérsia

Florescimento: Nos meses de junho, julho, agôsto até setembro, florece abundantemente.

$O$ néctar $e$ as abelhas : Flôres são muitíssimo visitadas por abelhas. O néctar deposita-se entre o ovário e os estames: Flôres de fácil acessos às abelhas, que para a coleta do néctar introduzem a língua por entre os estames livres.

Concentração do néctar em açúcares : $38,36,36,37,33,38$, $37,34,35,36,38,38 \%$, (cada um dos valores corresponde ac) néctar de uma flor), em 3-8-54, às 11 horas. C. M. 36,6.

Nectário: E' um disco carnoso, hipógino, amarelo-esbranquiçado, localizado no topo do receptáculo, sustentando o ová- 


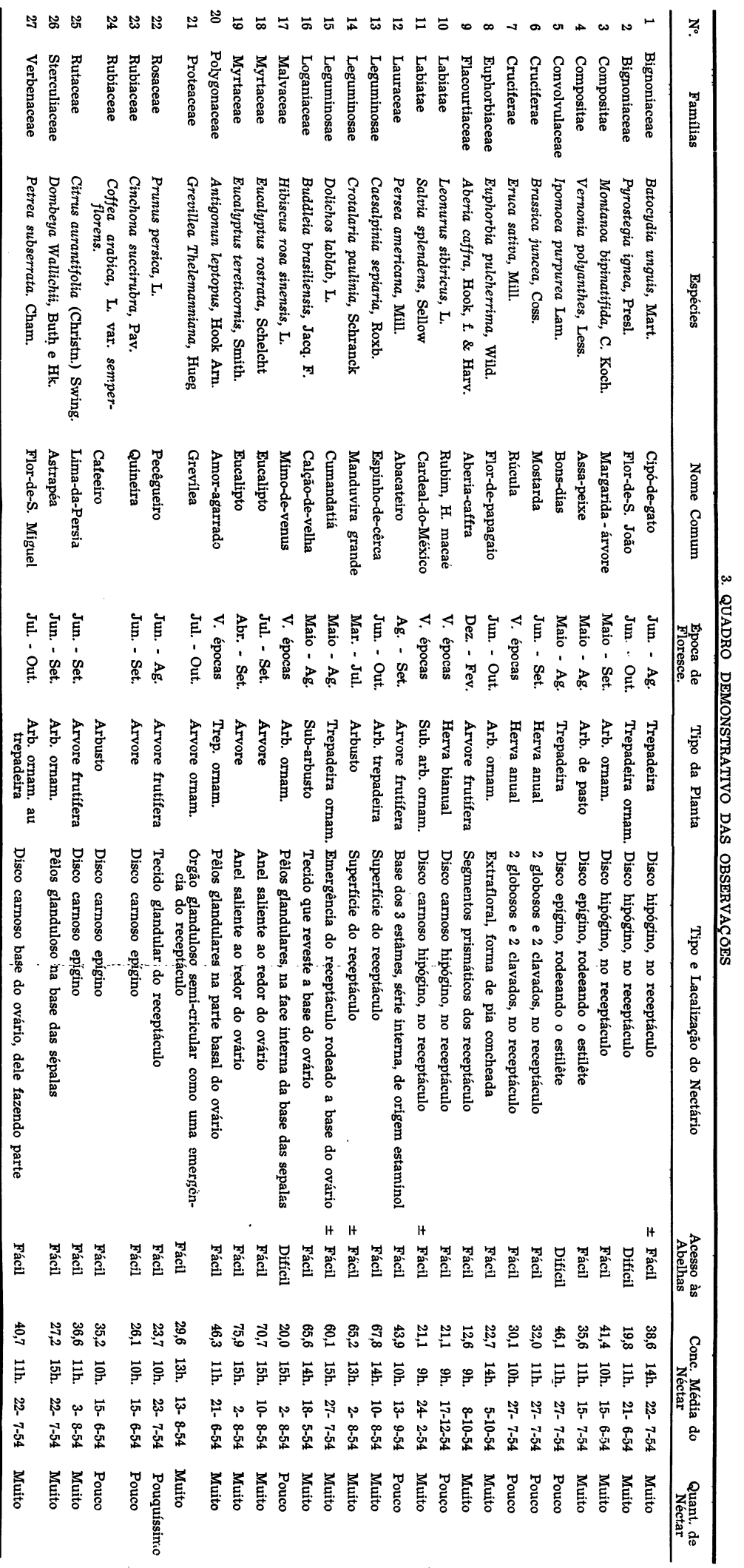


rio (Fig. 9,D.). A produção do néctar é relativamente grande, razão pela qual a espécie referida é considerada como uma das melhores plantas nectáriferas, apesar do seu período de florescimento não ser longo.

\subsection{Família Sterculiaceae}

Dombeya Wallichii, Bth e Hk.

Nome vulgar: Astrapéia

Florescimento: Floresce nos meses de junho, julho a aggessto até começo de setembro, produzindo de 40 a 50 flôres por cacho. Há, em média, uma produção de 100 a 200 cachos por re em cada planta com 3 a 4 anos.

O néctar $e$ as abelhas: As flôres são visitadíssimas pelas abelhas, ávidas de seu abundante néctar, que se acumula entre a base das pétalas e o tubo estaminal. A corola, apesar de ser dialipétala, tem a forma campanulada, o que facilita a retenção do néctar no seu interior. A disposição das pétalas é inbricada, deixando um espaço triangular sôbre o nectário, por onde se escoa o néctar.

Concentração do néctar em açúcares : $25,28,28,27,26,28$, $28 \%$, (cada um dos valores corresponde ao néctar de uma flor) em 22-7-54, às 15 horas. C. M. 27,2\%.

Nectário: Formado por um conjunto de pêlos glandulares, situados na base das sépalas, como uma pequena almofada, idêntico ao de Hibiscus rosa sinensis, L. A produção do néctar é tão abundante que conseguimos retirar $3 \mathrm{~cm}^{3}$ de néctar, de 52 flôres de um cacho apenas.

\subsection{Família Verbenaceae}

Petrea subserrata, Chm.

Nome vulgar: Flor-de-São Miguel ou Viuvinha

Florescimento: Floresce entre nós principalmente nos meses de julho, agôsto, setembro e outubro.

$O$ néctar $e$ as abelhas: As flôres são procuradas por abelhas que sugam o néctar acumulado, em relativa quantidade, no tubo da corola. As abelhas pousam na parte mais aberta da corola, introduzindo sua língua $(6,0 \mathrm{~mm}$ de comprimento) no tubo estreito ( $7 \mathrm{~mm}$ de comprimento) da mesma, retirando o néctar. Como a corola é caduca, após a sua quéda encontra-se pouco néctar no tubo do cálice (persistente).

Concentração do néctar em açúcares : 40, 41, 39, 40, 41, 39, $40,40,40 \%$, (cada um dos valores corresponde ao néctar de uma flor) em 22-7-54, às 11 horas. C. M. $40 \%$. 
Nectário: Rodeando a base do ovário e dele participando, encontramos um disco carnoso, mais saliente em uma das faces, formado por um tecido secretor, responsável pela secreção do néctar.

\section{RESUMO E CONCLUSOES}

Dos estudos feitos sóbre as 27 espécies apicolas anotamos a época de florescimento, localização e forma dos nectários, bem como a produção e concentração média do néctar de cada uma delas. Investigámos também si as flôres, pela sua conformação, eram ou não de fácil acesso às abelhas (Apis e Trigona) para a coléta do néctar.

Os nectários encontrados nessas 27 espécies podem ser divididos em dois grupos: 1 - os nectários extra-florais, encontrados em Euphorbia pulcherrima; 2-nectários florais os res. tantes. Sendo que a maior parte tem a sua localização no receptáculo floral, como um apêndice do mesmo, de consistência carnosa, com fórmas variadas, tais como disco, elmo, emergên. cias laminares, glândulosas etc.

As espécies estudadas têm, na maioria, o seu florescimento durante o periodo de maio a outubro e permitem fácil acesss: às abelhas Apis e Trigona.

Quanto à concentraçäo média dos néctares, verificamos que duas delas (Eucalyptus tereticorais, E. rostrata) apresentaram elevadíssima concentração $(70$ a $80 \%)$ de açúcares; 5 delas (Caesalpinea sepiaria. Crotalaria paulina, Dolichos lablab, Buddleia brasiliensis, Persea imericana) apresentavam elevada concentração (60 a $70 \%$ ) de açúcares; outras 5 (Petrea subserrata, Montanoa bipinatifide, Vernonia polyanthes, Salvia splendens e Antigonus leptopus,) apresentavam mediana concentarção (40 a 60\%); outras 9 (Bactocydia unguis, Ipomoea purpu. rea, Brassica juncea, Eruca sativa, Grevilea Thelemaninna, Prunus persica, Cinchona succirubra, Coffea arabica, Citrus aurantifolia, Dombeya Wallichii), apresentavam uma concen. tração um pouco mais baixa (25 a $40 \%)$ de açúcares, e as demais espécies com uma concentração fraca (entre 10 a $25 \%$ ).

Levando-se em consideração a quantidade e a concentraçãis do néctar, época de florescimento, conformação da flor, posiçäo e fórma dos nectários, a facilidade da coléta do néctar pelas abelhas, concluimos que a maioria das espécies estudadas merecem figurar na categoria de plantas nectariferas de valur apicola. 


\section{BIBLIOGRAFIA}

BAILEY, L. H., 1949 - Manual of Cultivated Plants. 1.116 pp. The Mac Millan Company New York.

BONNIER, Gaston, 1879 - Les Nectaries. Annales des Sciences Naturalles butanique. Liditor G. Masson. Paris. 212 p. Tome VIII.

HOWES, F. N. D. Sc., 1945 - Plants and Beekeping. 224 pp. Faber and Faber. Limited. London.

HOEHNE, F. C., 1940 - Flora Brasilica. Fasc. 2. Vol. XXV, II; 122. Secreiarıa da Agricultura, Industria e Comercio de São Paulo.

KUHLMANN, M. e Kuhn, Eduardo, 1947 - A Flora do Distrito de Ibiti. Secretaria da Agriculıura de S. Paulo.

LOEFGREN, Alberto, 1891 - Flora Paulista. Boletim n. 12. Comissão Geografica e Geologica de São Paulo.

ORDETX, Gonzalo S., 1952 - Flora Apicola de la America Tropical. 334 pp. Editoral Lex. Cuba.

PELLET, Franck. C., 1947 - American Honey Plants. Fourth Edition. 467 pp. Orange Judd Publishing Companny, Inc. New York.

PIO CORREA, M., 1926, 1931, 1952 - Dicionario das Plantas Uteis do Brasil e das Exoticas Cultivadas. Ministerio da Agricultura, Industria e Commercio. Vol. I, II, e III. Imprensa Nacional. Rio de Janeiro.

TOLEDO, J. F. e ELPING, C., 1943 - Flora Brasilica. Fasc. 7 (Vol. XLVIII; 1-14). Secretaria de Agricultura. Industria e Commercio de São Paulo.

VANSELL, G. H., 1931 - Nectar and Pollen Plants of California. Bulletin 517. 76 pp. University of California. Berkeley, California. 


\section{LEGENDAS}

Fig. 1 - Flor de Montanoa bipinatifida, C. Koch sem a corola; A-pedúnculo floral bem curto; B - ovário; C-nectário; $\mathrm{D}$ - estilête; E-estigma bífido. Aumento 10x. (Original).

Fig. 2 - Flor de Brassica juncea, Coss. sem o perianto, mostrando apenas dois estames maiores e dois menores; A --pedúnculo; B - receptáculo; C - nectários; D - estame (filête); $\mathrm{E}$-ovário; F-estilête. Aumento aproximado $6,6 \mathrm{x}$. (Original).

Fig. 3-Inflorescência de Euphorbia pulcherrima, Willd; Apedúnculo; B - invólucro globoso da inflorescência; C nctário extrafloral ("pia concheada"); D-estame; E-ovário; F - estigmas. Aumento 2-x. (Original).

Fig. 4-Flor de Leonurus sibiricus, L. sem o perianto e o androceu; A - pedúnculo; B - receptáculo; C-nectário; D - ovário; E-estilête. Aumento aproximado 6,6 x. (Original).

Fig. 5-Flor de Salvia splendens, Sellow sem o perianto e o androceu; A - pendúculo; B - receptáculo; C - nectário; D ovário; E-estilète. Aumento $10 \mathrm{x}$. (Original).

Fig. 6-Estame da série interna de Persea americana, Mill.; A - base comum do estame e dos nectários; B - nectários (Origem estaminal); C-filête; D-antera. Aumento $16 \mathrm{x}$. (Original).

Fig. 7 - Flor de Grevillea Thelemanniana, Hueg. sem o perianto; A - pedúnculo floral; B - receptáculo;- C - nectário; D ovário; E-estilête. Aumento 15 x. (Original).

Fig. 8-Flor de Coffea arabica, L. var. Semperflorens sem a corola e os estames; A - pedúnculo floral; B - ovário; C - cálice; D-nectários; E-estilête; F-estigma bifido. Aumento $8 \mathrm{x}$. (Original).

Fig.9 - Flor de Citrus aurantifolia (Christm.) Swing. sem corola e androceu; A - pedúnculo floral; $\mathrm{B}$-receptáculo; $\mathrm{C}$ cálise; D-nectário; E-ovário; F - estilête; G - estigma. Aumento $4 \mathrm{x}$. (Original). 


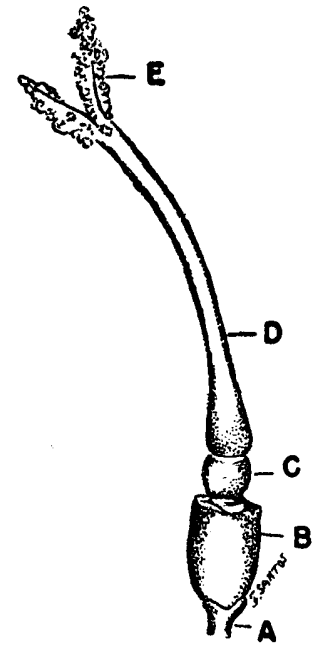

Fig. 1

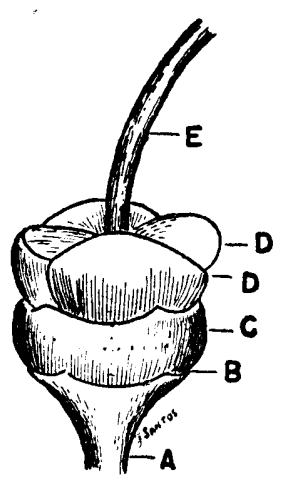

Fig. 4

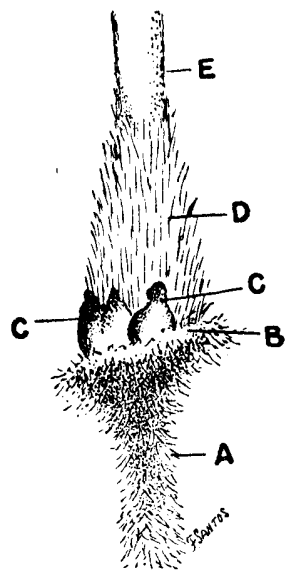

Fig. 7
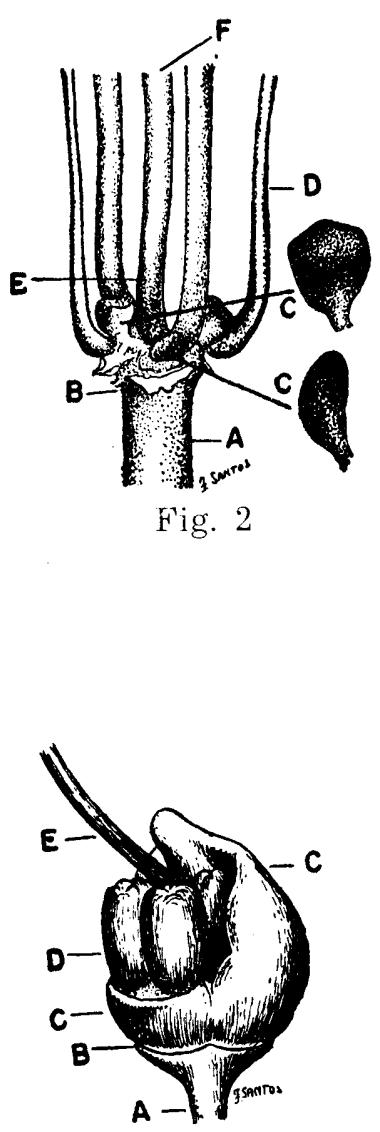

Fig. 5

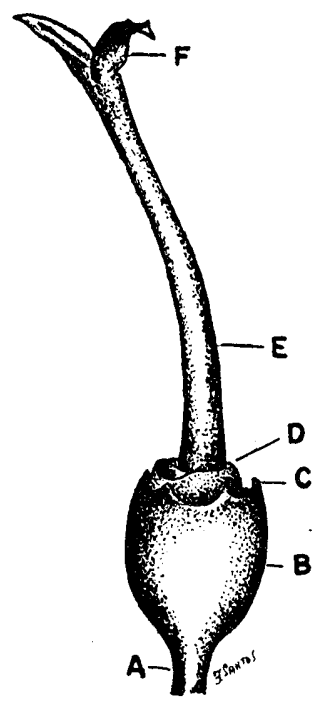

Fig. 8

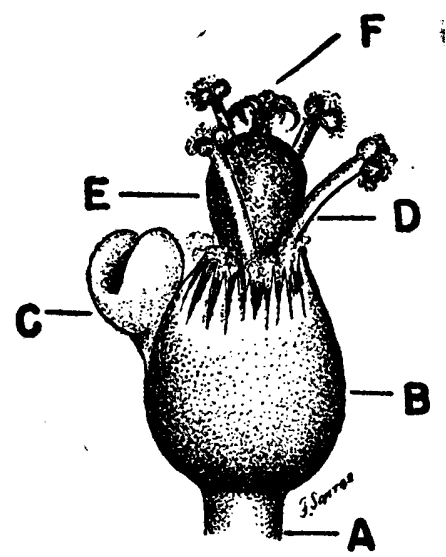

Fig. 3

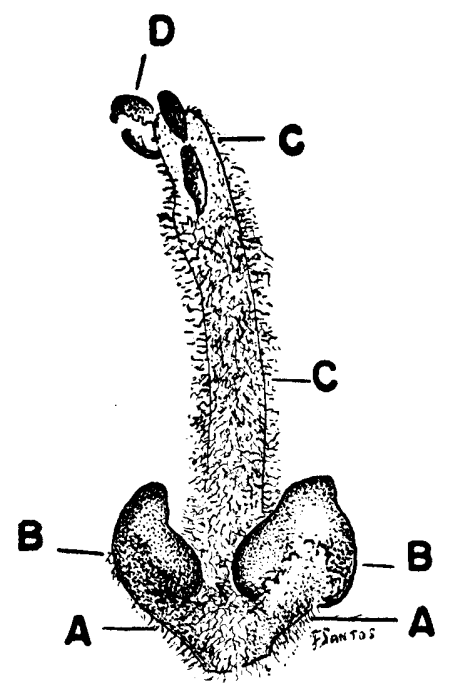

Fig. 6

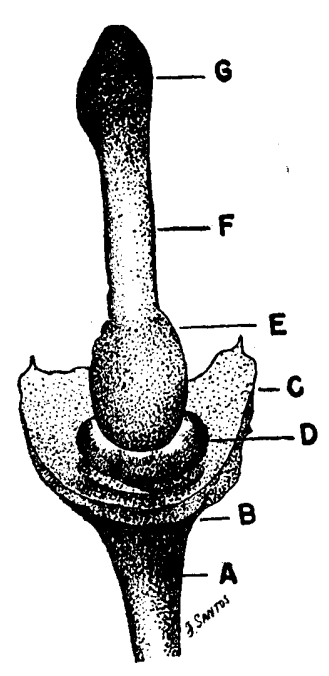

Fig. 9 
